Disponível em:

http://editora.unoesc.edu.br/index.php/race

RACE, Joaçaba, v. 16, n. 3, p. 827-844, set./dez. 2017

\title{
HABERMAS, THE CONCEPTUAL DEBATES ABOUT PUBLIC-PRIVATE-SOCIAL SPHERES AND THE COMMUNICATIVE ACTION IN ORGANIZATION THEORY
}

Habermas, os debates conceituais sobre as esferas pública-privada-social e a ação comunicativa na teoria das organizações

Felipe Fróes Couto

E-mail: felipe.couto@unimontes.br Mestre e Doutorando em Administração pela Universidade Federal de Minas Gerais; Professor na Universidade Estadual de Montes Claros.

\begin{abstract}
Alexandre de Pádua Carrieri
E-mail: alexandre-carrieri@ufmg.br Doutor em Administração pela Universidade Federal de Minas Gerais; Mestre em Administração pela Universidade Federal de Lavras; Professor Titular na Universidade Federal de Minas Gerais. Endereço para contato: Avenida Antonio Carlos, 6627, Pampulha, 31270901, Belo Horizonte, Minas Gerais, Brasil.
\end{abstract}

Artigo recebido em 30 de novembro de 2016. Aceito em 27 de junho de 2017. 
Abstract

In this essay, we aim to delineate elements of the Habermas and Hannah Arendt theories about the division between public, private and social spheres, as well as about communicative action in Habermas, in an attempt to convey transpositions of these concepts into the field of organizations. The analysis of the basics of Habermasian construction allows us to take a direct look at the delimitation of the field of interactions and the adoption of linguistic categories of analysis directed to the individual in the environment. Our argument is that the analysis of language in the world of life, for Habermas, means questioning what has not been receiving attention and "discovering" what is hidden in the linguistic universe of human interaction and intention.

Keywords: Public sphere. Private sphere. Social sphere. Communicative sction. Jürgen Habermas.

\section{Resumo}

Objetivamos, neste ensaio, delinear didaticamente elementos das teorias de Habermas e Hannah Arendt sobre a divisão entre as esferas pública, privada e social, bem como sobre o agir comunicativo em Habermas, em uma tentativa de aduzir transposições desses conceitos para o campo das organizações. A análise das noções básicas da construção habermasiana permite dar um olhar direcionado à delimitação do campo de interações e à adoção de categorias linguísticas de análise voltadas para o indivíduo no meio. Nosso argumento é que a análise da linguagem no mundo da vida, para Habermas, significa questionar o que não vem recebendo atenção e “descobrir” o que está oculto no universo linguístico da interação e da intenção humana.

Palavras-chave: Esfera pública. Esfera privada. Esfera social. Ação comunicativa. Jürgen Habermas.

\section{INTRODUCING HABERMAS IDEAS}

Knowing and analyzing facts of life from the perspective of Habermas's (1989) communicative action theory is one of the most complex missions for critical researchers in the social sciences. Complex because these are arid readings, but whose ideas have great transformative potential of human action, especially with regard to communication and consensus. Habermas, born in 1929, was a pupil of Horkheimer and Adorno at the Frankfurt school, and grew up under the Nazi regime, living the economic turmoil of the interwar period. His books, articles, and other productions are strongly marked by his attachment to the writings of Kant, Hegel, and Marx which made his production esoteric and loaded with an unnecessarily heavy style (BRONNER, 1997). Indeed, reading the Habermasian work requires concentration, dedication, and remarkable sensitivity and taste for the subjective theoretical constructs that mark his writing. 
Despite the difficulties we have just described, we assume that what causes attraction to Habermas's work, rather than the eloquence or complexity of reading his texts, is the potential of his ideas as means of emancipating man. Habermas is an author who remains attached to the critique of reification, reflexivity and, above all, the emancipation of individuals from all forms of domination (BRONNER, 1997). Throughout his career, he has elaborated one of the most profound studies on the subject of rationality in society and has influenced dozens of authors around the world interested in the emancipation of man from the constraints imposed by modern industrial society (SERVA, 1997).

The essence of Habermasian ideas is actually relatively simple. In a context of conflictual modernity, he was concerned with the public and non-violent force of the best argument for the conduct of human relations, rather than any militarized action or non-rational domination of society (HUXLEY, 2000). What many would consider a utopia, Habermas took to the extreme from his theory of human rational action and communication as central elements of democracy (HUXLEY, 2000).

What Habermas has envisioned is a scenario in which humans could base their relations through consensus and agreements, from conversations provided with understanding facility, integrity, legitimacy and truth. A critical realist epistemological posture based on American pragmatism and linguistic philosophy - a combination whose purpose was to give a new democratic impulse to critical theory - is assumed (BRONNER, 1997).

Transposing this philosophical construction to the theory of organizations means, more than dedicating hours to the understanding of texts, to open the possibility of a profound treatment of the complexity of social phenomena in organizations, precisely because it provides an alternative logic to traditional sociological analysis, since the focus on the intersubjective relationship between the subject and the other through language can provide a theoretical basis capable of leading to emancipation in organizations (STEFFY, GRIMES, 1986; VIZEU, 2005).

Without the pretension of exhausting the subject, the proposal of this essay is to delineate elements of these theories and to adduce some transpositions for the organizational theory. For this, this paper is subdivided into three sessions. In the first session, this brief introduction. In the second session, the discussion on the subdivision of the public, private and social spheres from a parallel between Habermas and Hannah Arendt. Finally, in the third session will be presented designs on the communicative action of Habermas together with the reflections of the reflective exercise carried out. 


\section{THE CONCEPTUAL SEPARATION OF THE PUBLIC, PRIVATE AND SOCIAL SPHERES}

A series of philosophical dilemmas arises at every attempt to conceptually delimit the public, private, and social spheres. To discuss the issue forces the researcher and the theorist to run the risks of reflective reductionism or analytical incompleteness given the unimaginable range of issues that may arise from the simple question "What is the public sphere?"

Sketching these boundaries can be an endless rhetorical exercise once the difficulty of understanding the boundaries between spheres is revealed. We propose that the analysis of this merit can be made from Habermas (1984) in parallel with the vision proposed by Arendt (1997), since the two authors indirectly establish points of convergence in relation to the subject, even though they have not discussed directly on this theme.

The distinction between the public and private spheres in Arendt's (1997) thought starts from the view on life and the social environment; after all, the environment is constituted of human activities, and human activities would have no meaning without existence within an environment. Thus, if all human activities are conditioned by the fact that the human being lives with other human beings, it is not possible to imagine human action outside the social context - therefore, action is the exclusive attribute of man as a social being (ARENDT, 1997).

If action is conditioned to the social environment, it is not only the satisfaction of individual interests, but political actions that echo in other men. According to Arendt (1997), the association of man and the emergence of the city-state means that man possesses, in addition to his private life, a kind of second life, or your bios politikos. Therefore, "every citizen belongs to two orders of existence; and there is a big difference in your life between what is his own (idion) and what is common (koinon)" (ARENDT, 1997, p. 34).

The bios politikos consists, according to Aristotelian philosophy, of two activities: the action (praxis) and discourse (lexis) - which are nonviolent, coeval and coequal trading activites - where the use of the word, or the act of looking for the right words at the right time, has the fundamental political action status of life in society (ARENDT, 1997).

Communication and discourse gradually become the central elements of men's public life (HABERMAS, 1984). According to Arendt (1997), communication becomes one of the elements of the arena of interests between men and mediates 
conflict between them; living in society means producing discourses with a view to persuading others by peaceful means without the use of despotic power typical of domestic organization:

In the experience of the polis, which for some reason has been considered the most loquacious of the political bodies, action and discourse have separated and become increasingly independent activities. The emphasis has shifted from action to discourse, and to discourse as a means of persuasion not as a specifically human way of responding, replicating, and confronting what happens or what is done. The political being, the living in a polis, meant that everything was decided by words and persuasion, not by force or violence. For the Greeks, to force someone through violence, to command rather than to persuade, were pre-political ways of dealing with people, typical of life outside the polis, characteristic of the home and of family life, in which the head of the house prevailed with uncontested and despotic powers. (ARENDT, 1997, p. 35-36).

From this, a distinction emerges between the public and private spheres. While in the first one the exercise of power is conditioned by persuasion and discourse, in the last one the dynamics of the exercise of power derives from the family arrangement, determined according to the intimate needs of each individual (HABERMAS, 1984; ARENDT, 1997). Arendt (1997) understands that the primitive family sphere is characterized by human need and lack and by the "obvious" division of the task of survival by the work of man and the task of the woman to perpetuate the species. Therefore, "the natural community of the home arose out of necessity: it was the need that prevailed over all activities carried out in the home” (ARENDT, 1997, p. 40).

For Habermas (1984), the private man status combines the householder's paper with merchant lord's one - while he is a man, he is also owner of goods. In this sense, the origin of human interests that are opposed in the public sphere lies in the needs, interests and subjectivities resulting from the private sphere, which, in other words, means that the public nature of public power is influenced by the political reasoning of private persons. Thus, the private sphere comprises bourgeois civil society in the narrow sense, that is, the commodity and labor exchange sector; the family, with its inner sphere, is just another dimension of a larger universe (HABERMAS, 1984).

It is observed, therefore, that the private sphere notion is intrinsically linked to the intimate interaction based on concepts of human needs, work, property and interests. These are to be the presuppositions of the individual, of the private. 
The public sphere, on the other hand, is the sphere of freedom, and its existence presupposed victory over the needs of family life (ARENDT, 1997). The public sphere, according to Bronner (1997) and Habermas (1984), is the space of freedom of man, in which he can exercise his full humanity without any kind of violent constraint: the public sphere is seen as mediating the state and Economic and political forces. The public sphere

[...] presupposes equality and the ability of the "common man" to employ "common sense". The public sphere is the arena where civil liberties are put into practice [...]. Indeed, with its emphasis on free speech and universal values, the public sphere becomes a sociological starting point for, ultimately, a philosophical concern with the role of discourse in advanced industrial society. (BRONNER, 1997, p. 346).

For Habermas (1984), the public sphere appears more intensively in the bourgeois layers, by means of the supplementation of the sphere of familiar intimacy and by the direct influence of that in the intimacy of the individuals. For Habermas, this supplementation occurs to the extent that "sleeping and living rooms are under one roof; and since the privacy of one depends on the public nature of the other, the subjectivity of the private individual is from the beginning linked to publicity" (HABERMAS, 1984, p. 67-68). The public in this sense adopts the connotation of arena, or of the world in which we live, in the measure that is common to all.

In other words, the private sphere is contained in the public sphere. First, needs are overcome in the private sphere, contained in the public sphere; overcoming these needs allows access to the public sphere and political debate. For Arendt (1997), this relation can be symbolized by means of a metaphor: the discussion table. First, each one must get his seat at the table (to overcome his or her intimate needs), and then participate in an arena that, at the same time, unites and separates the individuals and their respective interests, as each one has a place together to the table - that was designed to unite people in the same environment, placing them in their proper places (ARENDT, 1997).

What about the social sphere? According to Arendt (1997), the social sphere is the elevation of the domestic home or of economic activities to the public level, insofar as the domestic administration and all matters pertaining to the private sphere have become collective interest. According to Habermas (1989), the social sphere is the result of the bourgeois articulation that takes place in the inner sphere, in the great 
domestic halls where those who owned goods and rights could talk and create coalitions to bring their interests to the public sphere. Those interests which, according to the author, arose from the shared feeling of an economic, patrimonial and labor domination exercised by the nobility and the clergy to the detriment of the bourgeoisie:

\begin{abstract}
As the state and society interpenetrate, the institution of the stricto sensu family stands out from the processes of social reproduction: the inner sphere, once the center of the private sphere in general, retreats to its periphery as it becomes deprived. These two spheres, once structured in the same direction, now develop in the opposite way: "and one can effectively say that the family becomes increasingly private, while the world of work and organization becomes more and more public". The term "world of work and organization" already reveals something of the tendency towards the objectification of a sector formerly considered to be subject to private devices, whether it was the owner's own property that he had, whether it was for the employee, of a property which he did not enjoy. (HABERMAS, 1984, p. 180-181).
\end{abstract}

Continuing this distinction in which distinct spheres of public-public and public-social affairs arise, Habermas (1984) argues that the functioning of the social sphere, unlike the public sphere itself, is governed by the conflict between public opinion and public power. The scope of the traditional public sphere shifts from traditionally political tasks (social order, jurisdiction) to the civil tasks of a society that publicly debates the economy and the exchange of commodities (HABERMAS, 1984). The bourgeoisie, in the social sphere, then seeks to stand the interests arising from private experience in polemical opposition to the res publica politically established by the monarchical state.

It is in the social sphere that the professional enterprise evolves into a quasi-public sector in front of a private sphere reduced to the family (HABERMAS, 1984). Time not occupied by professional activities delimits exactly what is the inner sphere of individuals, or their reserve of the private. With large corporations (or organizations), dominant types of social work organization arise in the face of the separation between the private sphere and the public sphere, which Habermas (1984) typifies as a neutral sphere. Organizations, then, become an expression of neutrality in the social sphere, which is neither wholly public nor totally private. 
The dissatisfactions with the private sphere, then, not being able to be transmitted to the public sphere, are transmitted to the social sphere. The tensions of the public sphere and its incapacities to attend to all the interests of the citizens, in the same way, not being able to be transmitted also to the private sphere, are also transmitted to the sphere of the social. Organizations, in this sense, become central actors of the social sphere:

The companies build houses or even help the employee to build
a house, form public parks, build schools, churches and libra-
ries, organize concerts and theater sessions, maintain courses of
improvement, provide for the elders, widows and orphans. The
oikos of a large company thus determines the life of a city and
carries a phenomenon that, properly, is designated as industrial
feudalism. The same applies mutatis mutandis to the large ad-
ministrative bureaucracies of the metropolis, losing its public
character (in the sociological sense) to the same extent that turn
into large companies. (HABERMAS, 1984, p. 183).

More striking than these structural changes are the changes that occur in the subjectivity of individuals. Organizations become the intermediary institutions between people and the public. They become arenas of clashes in which the public and private spheres are confused. Where individuals take their needs and seek their fulfillment; at the same time that work, the social order, and the normative system are discussed and implemented. Each person who previously worked only in his or her private sphere now goes on to work publicly and goes off in favor of the labor relationship which, more than anything else, establishes a greater link between employee-organization than with other people (HABERMAS, 1984).

Addressing the social spheres of organizations, therefore, means much more than just understanding how the dynamics of negotiation and social control between individuals occur. It means working the intimate of the human being, his needs, his needs, his economic pretensions, in the same way that it means working the public purposes and the goals of action at work. It means understanding the discourses that shape the political dynamics that exist in a social sphere that shares an infinity of interests and pretensions through the appearance which constitutes reality (ARENDT, 1997), in the narration of stories in which people bring themselves in their subjective and original constructions. 


\section{COMMUNICATIVE ACTION THEORY: OUTLINING A THEORETICAL SENSE FOR ADMINISTRATORS}

Throughout everyday experiences, we often wonder, in situations of extreme difficulty, "why can we not reach agreement on simple solutions? It would be easier if we were able just to talk and reach a joint solution." In simple terms, the solution to mankind's conflicts lies in interaction and consensus. This is the initial premise of Habermas in developing his theory of communicative action, which starts from the assumption that consensus is possible from the understanding of actions as interconnected between individuals, even though diffuse interests are present (HABERMAS, 2002).

But consensus, like any social process, is complex and intersubjective. The theory of communicative action, according to Lima and Rivera (2009), is an interesting way to shift from centralized daily praxis to new, more democratic, integrated perspectives, based on solidarity, communication, searching for the best argument and consensus. Linguistic interaction, in this view, assumes a central role for the materialization of theoretical models capable of guiding human action for democracy and for the collective construction of society.

What differentiates the human being from other animals is the ability to understand their attitudes, gestures and the environment in which they are. Thus, according to Ferreira (2000), while we understand the world of life around us, we also understand that our actions are responsible for changes in the conduct of other individuals. For Ferreira (2000), the social act is characterized by a process of symbolic action and adaptation of each individual, through gestures, actions and reactions of other individuals. According to the author:

The use of gestures and the reflexive ability to think is what ultimately enables the human being to adopt the role of the other to regulate his or her own behavior. To the extent that a gesture represents the idea behind it and provokes that idea in another individual, one has a significant symbol, which represents a certain meaning; when the gesture arrives at this situation, one has a proper language. At the moment when the reaction of a second person is provoked by a first individual, becoming a stimulus to control the action of the first organism, then we have the significance of the act in the experience of that first individual. This relationship of mutual adaptation makes possible the emergence of consciousness [...] (FERREIRA, 2000, p. 37). 
As much as the human being means the action of the other, he also interprets the environment around him, or, as used by Habermas, the World of Life. The World of Life, a concept originally elaborated by Alfred Schutz (SERVA, 1997), means the subjective plane that already existed before our birth, and that was experienced and interpreted by all our predecessors as an organized world, and that it is up to us reinterpret it. However, for Habermas "the world of life does not fulfill only the function of context; It offers a provision of convictions, values, norms, to which participants in a communicative process make use of consensus-based interpretations." (SERVA, 1997, p. 116). The world of life, theoretically systematized, consists of: culture (such as the deposit of knowledge, where the human being draws its interpretations); society (legitimate ordinances by which men regulate their groups and properties) and finally; personality (the unique characteristics and motivations behind an action of a language subject) (FERREIRA, 2000). In this way, it is the cognition about scenery and other individuals that constitutes the field in which linguistic dynamics occurs.

The linguistic dynamic exudes from the communicative rationality of individuals and constitutes the externalization of human intentions. The Habermasian consensus, as understood by authors such as Conti and Pinheiro (2011) and Jerônimo (2014), refers to the dynamics in which individuals express their interests in the best way to convince others of their points of view, whether in search of consensus, or in search of social integration. When the individual seeks the transmission of information for an end, it is said that the use of language is a strategic action; When language is used for social integration and consensus, we are dealing with Habermas' communicative action (FERREIRA, 2000).

According to authors like Lima and Rivera (2009), Conti and Pinheiro (2011) and Jerônimo (2014), communicative rationality presupposes not only the relation between context, reasons, norms and argumentative discourse; but also the existence of a basis of mutually recognized claims of validity and the semantic content of the linguistic issue. In other words, "the concept of communicative action, elaborated by Habermas, refers to the interaction of at least two subjects capable of language and action that initiate an interpersonal relationship in which they seek to understand each other so that they can co-ordinate their plans of action.” (CONTI; PINHEIRO, 2011, p. 4). That is, communicative rationality refers to the ability to use argumentative discourse in favor of consensus without resistances that originate conflicts.

That is to say, in simpler terms, that the communicative action is the argument that wins by being true and according to the context; by having rational elements behind the communication that are compatible with the cooperative plan of 
individuals; which, although it may be contrasted with normative elements common to society, is not; And that it is accepted as a valid claim by the other to integrate a larger, collective plan that benefits everyone.

Communicative action forces individuals to abandon the egocentrism of a calculation that is exclusively oriented toward their own success. Under the functional aspect of understanding, communicative action serves the tradition and renewal of culture; Under the aspect of socialization, serves the formation of individual personalities; And under the aspect of coordination of action, it serves social integration and the creation of solidarity. (LIMA; RIVERA, 2009, p. 334).

In the words of the author himself,

Communicative action can be understood as a circular process in which the actor is both at the same time: he is the initiator, who dominates situations through imputable actions; at the same time, he is also the product of the traditions in which he finds itself, of the solidarity groups to which he belongs and of the processes of socialization in which he is created. While the situationally relevant segment of the world of life impinges on the agent, so to speak, frontally, as a problem that he has to solve on his own account, he finds himself sustained by a world of life, which not only forms the context for mutual understanding processes, but also provides the resources for this. The world of ordinary life in each case offers a provision of cultural truisms where the participants in the communication draw their efforts from interpreting the consented models of exegesis. (HABERMAS, 1989, p. 166).

Authors such as Ferreira (2000) and Huxley (2000) understand that Habermas rejects the philosophy of the subject and focuses on the problem of mutual understanding, which analyzes inter-subjectivity not only through the constructions of individuals, but of the language that expresses itself, and how it is given for consent. In this way, the author proposes to overcome the individuation stemming from the monological rationality, centered on the self, by the dialogical rationality, that is, the rationality through the discourse (FERREIRA, 2000; HUXLEY, 2000).

The concept of interest in dialogic rationality becomes central to the theory of communicative action and a link between the context and the application of knowledge (BRONNER, 1997). Language is always used for an end and presupposes the 
mutual understanding between a speaker and a recipient about something in the world (FERREIRA, 2000).

For Ferreira (2000), Habermas's observation that the intended meaning is mediated by linguistic signs indicates that the best form of analysis is the attention to language itself, and the triple relationship that it originates from the represented thing, the meaning and interpreters. Linguistic actions in this sense can take locutionary ways - ways in which the speaker seeks to express the state of things, registering facts, report events and say something without pretension. The illocutionary act, according to Ferreira (2000), is one in which the speaker does not report events, but directs his speech for their own actions or, in other words, it's his own conduct by stating his actions; on the other hand the perlocutionary act, "the speaker seeks cause an effect on the listener.” (FERREIRA, 2000, p. 73).

Strategic action is intimately related to the perlocutionary act, which aims at success through the influence of one individual over the other (be it to annoy, humiliate, dominate, etc.). The difference, according to Habermas, from the perlocutionary act in relation to the illocutionary one is that the last one is subject to rejection by the other and its success lies in the comprehension of language, whereas the first one is intimately connected to a desirable influence by the speaker and whose success is only effected by goal. Therefore, "the understanding and acceptance of discursive actions are indicative of illocutionary successes; the finalities that go beyond these are called perlocutionary ends.” (FERREIRA, 2000, p. 74).

The communicative action is closely linked therefore with the existence of illocutionary purposes, which cannot thus be achieved without mutual understanding, speech validation, cooperation and the free acceptance of the recipient - the consent itself.

Participants in the cooperative communication process are at the service of reaching a consensus under which they can coordinate action plans and realize their own intentions for action. The consensus sought should be achieved through a rationally motivated agreement, with the communicative action between the expectation of consensus and the risk of dissent [...] as the different spheres of value translate their own logic into social structures of the corresponding differentiated spheres of life [...] society can become a tension between institutionalized action orientations, that is, conflicts of action. (CONTI; PINHEIRO, 2011, p. 5). 
The emancipatory action, for Bronner (1997, p. 373), is affirmed “when one defines how individual group interests arise and how they become relevant to the exercise of freedom and enjoyment by others." The decentralized understanding of the world, based on the understanding of language, the actors behind its use, and the perception of the hidden ends embedded in the best argument constitute the essence of the emancipation of apparent problems for the analysis of the world of life and its real problems.

For Habermas (1989, p. 169), the more one advances in these differentiations, the more clearly two things separate: on the one hand, "a horizon of unquestioned truisms, shared intersubjectively and not thematized"; on the other, what lies ahead as hidden content constituted by communication, as manipulative objects, mandatory norms that violate, or even privileged access experiences hidden in society.

The analysis of language in the world of life means, therefore, to question what has not been receiving attention and to "discover" what is hidden in the linguistic universe of interaction and human intention. The purpose of this analysis is the search for a truly democratic and independent consensus of forms of human domination or of individual searches that assume linguistic forms of public interest. Undertake such analyzes demand, then, a deep knowledge of the field, the rules and elements that make up the world of life and understand the language as the source of questions that give rise to all problematizations that before were not made, and give attention to all that until then were ignored and can be largely, conflicts between individuals.

\section{CONTROVERSIES, APPLICABILITY TO ORGANIZATION THEORY AND SOME CONSIDERATIONS}

Despite Habermas’ great contribution to Organizational Studies in dealing with the matter of language and the dynamics of interaction and consensus among the subjects, his work has been criticized in other epistemological or theoretical approaches. In this sense, it is possible to identify at least three major fronts that highlight some weaknesses in the theory of communicative action. The first criticism is put by poststructuralists, who treat in a more utilitarian way the dynamics between the subjects. The second criticism is posited by the post-colonialist authors, who treat the question of ontology as a form of discursive domination and submission of entire societies. Finally, the third criticism comes from the liberals who have worked on the issue of the Bad Civil Society, which deals with the issue of certain social groups 
that freely and spontaneously adopted conducts considered morally reproachable to destruct or corrupt society.

The post-structuralist critique is led by French thinkers such as Foucault (2008a, 2008b) and Deleuze (1988, 2014), who deal with the issue of power asymmetries and the relations of forces between the subjects. By adopting a thought aligned with that of Nietzsche, the authors work power between subjects and forms of subjectivation as discursive practices of power, and understand that consensus will always be permeated by asymmetries between the subjects, which produce and are produced from intersubjectivity strategically elaborated by agents that aim to attend to their own wills. The dynamics of power and resistance in these authors is continuous and gives great focus to power disputes.

The post-colonialist critique is based on the theoretical constructions of authors like Escobar (1988), Mignolo (1993) and Dussel (1998). According to these authors, Habermas's discursive reason presents as a pretension of moral validity the consensus, that is, the right that every subject possesses to participate in communicative relations. As if the subjects had as premise the freedom, equality and dignity to participate, jointly, of a space of dialogue. However, what Dussel observes is that in political terms, Habermas's assumption of validity is not followed, for the colonized subjects were not, in no historical moment, allowed free speech. Caselas (2009), in this sense, goes further, and understands that in current political practices it is still possible to perceive the remnant of colonization in representative democracy, as only a few groups are heard by the State, while others are simply silenced or ignored in the political process.

Finally, the criticism of the theoretical front that studies the Bad Civil Society concerns the assumption that people can come together to form a consensus that not necessarily leads to the good and progress of civil society. This argument is posed by Chambers and Kopstein (2001), for whom it is possible for groups to come together not for construction but for the destruction of society, that is, groups that adopt at their own will precepts that go against morality and the socially established rules. In the view of these authors, consensus will not always result in something positive for maintaining the conditions of life in society.

Despite criticism, Habermas’ work has great applicability to studies dealing with the public sphere as a space for deliberation and consensus for the achievement of social and political goals in democratic regimes. The work has been directed at the issues of the mechanisms or forms by which an adequate political deliberation can be taken and will, procedurally, attend to the collective interests (BEVIR; RHODES, 
2016). In the same way, it has been used as a reference for the development of research that deals with the construction of public policies (BRUGUÉ-TORRUELLA, 2014). In Brazil, studies on communicative action focus on political objects such as social movements (GOHN, 1997, 2001), municipal councils and participation in public management (MARTINS, 2015). The contributions have been relevant in order to allow a greater understanding of the dynamics between the subjects in such contexts. In the same way, it has been possible to understand how the dynamics of interests between agents occur in contexts of political deliberation and what are the possible obstacles to the possible consensuses among social groups.

Finally, we consider that the potential of the theory can still be explored more deeply in relation to private organizations, given its social nature. It is important to recognize that companies are composed of relations of both the public sphere and the private sphere. In Brazil, for example, we have the development of theoretical studies on the ethics of the subjects, the relations of consensus, of collective construction and on the resistance inside the companies (VASCONCELOS; PESQUEUX; CYRINO, 2014; MATTIA; ZAPPELLINI, 2014). On the other hand, we have studies about the relations of companies with the State, with society and with the environment - what projects the companies for external political relations that affect the collective in general way (PESQUEUX; VASCONCELOS, 2013). The possibilities for the application of the theory of communicative action and of the analysis of the subject's action in the public, private and social spheres are extensive and can inspire new visions and approaches on contemporary problems that constitute the obstacles of the 21st Century, especially with respect to the search for the fullness of democracy.

\section{REFERENCES}

ARENDT, H. A condição humana. 8. ed. Rio de Janeiro: Forense Universitária, 1997.

BEVIR, M.; RHODES, R. A. W. (Ed.). Rethinking Governance: Ruling, rationalities and resistance. Routledge, 2016.

BRONNER, S. E. Jürgen Habermas e a Linguagem da Política. In: BRONNER, S. E. Da teoria crítica e seus teóricos. Campinas: Papirus, 1997.

BRUGUÉ-TORRUELLA, Q. Políticas públicas: entre la deliberación y el ejercicio de autoridad. Revista Cuadernos de Gobierno y Administración Pública, v. 1, n. 1, p. 37-55, 2014. 
CASELAS, J. M. S. A utopia possível de Enrique Dussel: a arquitetônica da Ética da Libertação. Cadernos de Ética e Filosofia Política, n. 15, p. 63-84, 2009.

CHAMBERS, S.; KOPSTEIN, J. Bad civil society. Political Theory, v. 29, i. 6, p. 837-865, 2001.

CONTI, C. L. A.; PINHEIRO, E. V. Participação e conflitos na gestão de uma escola transformada em comunidades de aprendizagem. In: SIMPÓSIO DA ANPAE, 25., 2011, São Paulo. Anais... São Paulo: Anpae, 2011.

DELEUZE, G. El Poder: curso sobre Foucault II. 1. ed. Ciudad Autónoma de Buenos Aires: Cactus, 2014. 416 p.

DELEUZE, G. Foucault. Minneapolis, Minnesota, United States: University of Minnesota Press, 1988.

DUSSEL, E. Ética de la Liberación (Hacia el’punto de partida'como ejercicio de la'razón’ética originaria). In: Dussel, E. La ética de la liberación ante el desafío de Apel, Taylor y Vattimo. México: Universidad Autónoma del Estado de México, 1998.

ESCOBAR, A. Power and visibility: Development and the invention and management of the Third World. Cultural Anthropology, v. 3, i. 4, p. 428-443, 1988.

FERREIRA, R. M. Individuação e Socialização em Jürgen Habermas. Belo Horizonte: Unicentro Newton Paiva, 2000.

FOUCAULT, M. O Nascimento da Biopolítica: curso dado no Collège de France (1977-1978). São Paulo: Martins Fontes, 2008a.

FOUCAULT, M. Segurança, território, população: curso dado no Collège de France (1977-1978). São Paulo: Martins Fontes, 2008b.

GOHN, M. da G. Movimentos sociais, ONGs e Terceiro Setor: perspectivas para a solução. [S.l.]: [s.n.], 2001.

GOHN, M. da G. Teorias dos movimentos sociais: paradigmas clássicos e contemporâneos. São Paulo: Edições Loyola, 1997.

HABERMAS, J. Consciência Moral e Agir Comunicativo. Rio de Janeiro: Tempo Brasileiro, 1989. 
HABERMAS, J. Mudança Estrutural da Esfera Pública. Rio de Janeiro: Tempo Brasileiro, 1984.

HABERMAS, J. Racionalidade e comunicação. Lisboa: Edições 70, 2002.

HUXLEY, M. The limits to communicative planning. Journal of Planning Education and Research, p. 369-377, 2000.

JERÔNIMO, L. S. de O. Dimensão Argumentativa da participação cidadã no processo deliberativo: perspectiva habermasiana de racionalidade comunicativa na consulta pública online. Comunicación Y Ciudadanía, n. 86, 18 p., abr./jun. 2014.

LIMA, M. C.; RIVERA, F. J. U. Communicative action, networks of conversation and coordination in healthcare services: a theoretical and methodological perspective. Interface - Comunic., Saude, Educ., v. 13, n. 31, p. 329-42, out./dez. 2009.

MARTINS, S. O Exercício da Democracia em Conselhos de Políticas Públicas. 2015. Tese (Doutorado em Administração)-Universidade Federal de Minas Gerais, Belo Horizonte, 2015.

MATTIA, C.; ZAPPELLINI, M. Ética e coprodução de serviços públicos: uma fundamentação a partir de Habermas. Cadernos EBAPE.BR, v. 12, n. 3, p. 573-573, 2014.

MIGNOLO, W. D. Colonial and postcolonial discourse: cultural critique or academic colonialism? Latin American Research Review, v. 28, i. 3, p. 120-134, 1993.

PESQUEUX, Y.; VASCONCELOS, I. F. F. G. de. Communicative Action Theory and company's social responsibility: a research proposal. Cadernos EBAPE.BR, v. 11, n. 1, p. 30-40, 2013.

SERVA, M. Abordagem substantiva e ação comunicativa: uma complementaridade proveitosa para a teoria das organizações. Revista de Administração Pública (RAP), Rio de janeiro, v. 31, n. 2, p. 108-134, mar./abr. 1997.

STEFFY, B. D.; GRIMES, A. J. A critical theory of organization science. Academy of Management Review, v. 11, i. 2, p. 322-336, 1986.

VASCONCELOS, I. F. F. G.; PESQUEUX, Y.; CYRINO, A. B. A Teoria da Ação Comunicativa de Habermas e suas aplicações nas organizações: contribuições para uma agenda de pesquisa. Cadernos EBAPE.BR, v. 12, p. 374-374, 2014. Edição Especial. 
VIZEU, F. Ação Comunicativa e estudos organizacionais. Revista de Administração de Empresas, v. 45, n. 4, p. 11-21, out./dez. 2005.

\title{
Como citar este artigo:
}

\begin{abstract}
ABNT
COUTO, Felipe Fróes; CARRIERI, Alexandre de Pádua. Habermas, the conceptual debates about public-private-social spheres and the communicative action in organization theory. RACE, Revista de Administração, Contabilidade e Economia, Joaçaba: Ed. Unoesc, v. 16, n. 3, p. 827-844, set./dez. 2017. Disponível em: <http:// editora.unoesc.edu.br/index.php/race>. Acesso em: dia/mês/ano.
\end{abstract}

\section{APA}

Couto, F. F., \& Carrieri, A. de P. (2017). Habermas, the conceptual debates about public-private-social spheres and the communicative action in organization theory. RACE, Revista de Administração, Contabilidade e Economia, 16(3), 827-844. Recuperado em dia/mês/ano, de http://editora.unoesc.edu.br/index.php/race 